\title{
ANURANS OF THE EVERGLADES AGRICULTURAL AREA
}

A guide to frogs and toads in south Florida

Michelle L. Casler, Wendy M. Bear, Elise V. Pearlstine, Frank J. Mazzotti

\begin{abstract}
BACKGROUND
Frogs and toads, otherwise known as anurans, are the most widely distributed order of amphibians and have the most species with more than 4,000. Typically, toads have warty skin and short legs for hopping, and frogs have relatively smooth skin and long legs for leaping. Many species advertise their presence by vocalizations throughout the year, while others are rarely heard at times other than their breeding season. While some toads are adapted to dry environments most anurans have moist skin, making them prone to dessication. This generally confines them to wet or moist habitats; however the few that are adapted to dry environments avoid dessication by burrowing in the soil or hiding under logs and rocks to avoid the heat of the sun. A few species are fossorial, spending much of their lives underground, foraging on termites and ants.
\end{abstract}

The snout-vent length of anurans varies greatly. One of the smallest frogs, Eleutherodactylus iberia, is only $10 \mathrm{~mm}$ long, while one of the largest frogs, the Goliath Frog (Conraua goliath), can reach up to a foot in length.

Some anurans produce toxins known as bufotoxins or alkaloids. Most members of the family Bufonidae (toads) produce bufotoxins which are released through paratoid glands located at the back of the head. These bufotoxins may help the animal escape from predators if released when the toad is caught. Dendrobatids, tropical species commonly known as dart poison frogs, have high levels of alkaloids. Their toxins are strong enough to be lethal to humans. These frogs are brightly colored to help warn and deter predators.

Reproduction methods vary in anurans. The most common method of reproduction is via aquatic larvae known as tadpoles. Tadpoles hatch from eggs laid in, near or above water and most are herbivorous, feeding on plants. After a period of time, differing between species, the tadpole metamorphoses into an small frog or toad. All native anurans in south Florida reproduce by this method. The Greenhouse Frog (Eleutherodactylus planirostris), an introduced species, does not go through a tadpole stage. Young hatch directly out of eggs as tiny frogs known as froglets.

\section{DeClining AnURAnS}

Anurans are declining globally due to many different factors. The number one factor of anuran decline is habitat loss. Additional factors include predation by introduced exotic or game fish species, pollution, and over collecting for food or pet trade. Global factors such as climate change, increased ultraviolet radiation and infectious diseases are also implicated. The skin of an anuran is extremely permeable and absorbent in order to efficiently exchange gases and water. Due to this, it readily takes up pollutants or chemicals present in the water and soil.

\section{NON-NATIVE SPECIES}

There are three non-native species present in the Everglades Agricultural Area: the Greenhouse Frog, Marine Toad (Bufo marinus) and Cuban Treefrog (Osteopilus sepentrionalis). The Marine Toad produces bufotoxins that, when excreted through paratoid glands on its skin, can be harmful to humans and potentially fatal to pets such as cats 


\section{AnUrans of the Everglades Agricultural Area}

and dogs if ingested. Cuban Treefrogs eat other frogs such as the native Squirrel Treefrogs.

\section{ROLE/Benefits}

Anurans play a very important role in the ecosystem. They feed on insects and invertebrates, including those that may damage crops. Mosquitoes and ants are common food sources. Anurans also provide a valuable food source for wading birds, snakes, hawks, fish and other aquatic organisms. They are also an indicator of ecosystem health due to their sensitivity to pollutions in their environment.

\section{References AND Further ReAding MateriaL}

Carmichael, P., and W. Williams. 1992. Florida's Fabulous Reptiles and Amphibians. Tampa, FL: World Publications.

Collins, J.P., and A. Storfer. 2003. Global Amphibian Declines: Sorting the hypotheses. Diversity and Distributions 9:89-98.

Conant, R. and J. T. Collins. 1991. A Field Guide to Reptiles and Amphibians of Eastern and Central North America (3rd Edition). Boston, MA: Houghton Mifflin Co.

Pough, F.H., R.M. Andrews, J.E. Cadle, M.L. Crump, A.H. Savitzky and K.D. Wells. 2001. Herpetology (2nd Edition). Upper Saddle River, NJ : Prentice Hall

This is document Cir 1463, one of a series in the Department of Wildlife Ecology and Conservation, University of Florida. Authors are: Michelle L. Casler, Wendy M. Bear, Elise V. Pearlstine, Frank J. Mazzotti, Wildlife Ecology Department, University of Florida, Fort Lauderdale Research and Education Center, IFAS, Davie, FL 33314, (954) 577-6354. Contributors include J. Hardin Waddle and Kenneth G. Rice. All photos and drawings copyrighted by Michelle L. Casler, Wendy M. Bear and J. Hardin Waddle. Published December 2004.

\section{Dorsolateral Ridge}

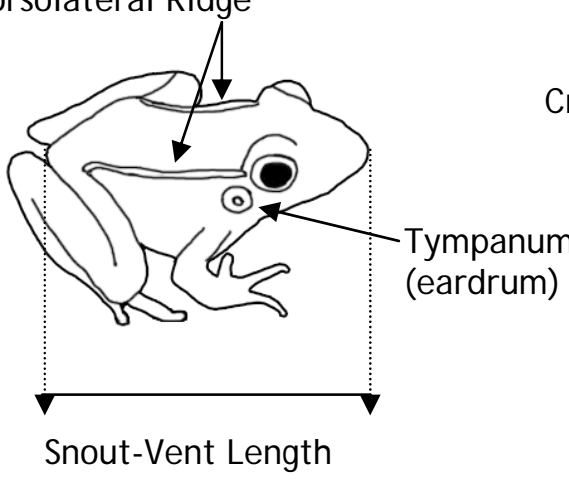

Typical Frog

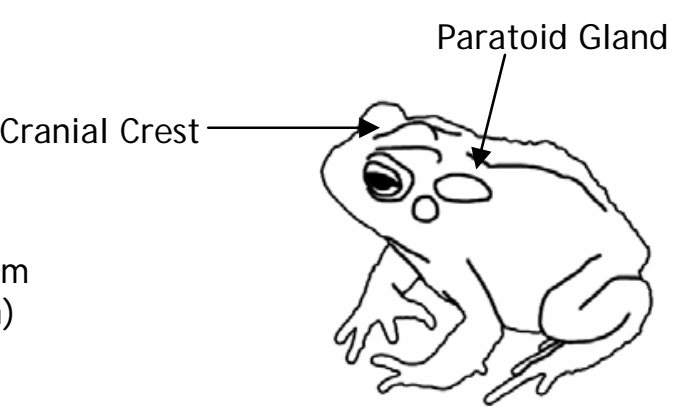

Typical Toad 


\section{AnUrans of the Everglades Agricultural Area}

\section{Guide to Anurans of the EAA}

Southern Toad Bufo terrestris

The Southern Toad is large, plump and approximately $1 \frac{5}{8}$ to 3 inches in length. It has pronounced knobs and high cranial crests. It is usually brown, but can vary from red to black, with or without dark spots containing 1-2 or more warts. This toad is widely distributed and abundant in sandy areas. It hides during the day, usually in self-dug burrows, and becomes active at twilight. Its voice is a high-pitched, musical trill lasting from 2-8 seconds.

\section{Oak Toad Bufo quercicus}

The Oak Toad has a conspicuous white to orange stripe down middle of its back. It is the smallest toad in North America, generally $3 / 4-1 \frac{1}{4}$ inches in length. Four to five pairs of black or brown blotches are present on its back. Its warts can be red, orange or reddish brown. Cranial crests on this toad are not apparent. It is primarily diurnal and is seldom seen at night, except in breeding choruses. Oak Toads are abundant in southern pinewoods and oak scrub. Its voice is similar to the peeping of newly hatched chicks.

\section{Southern Cricket Frog Acris gryllus}

The Southern Cricket Frog is red, black, brown or green with rough skin. A dark triangle is present between its eyes and it has longitudinal dark stripes on thighs. Its snout is pointed and hind legs are relatively long. The hind feet are webbed, but the webbing does not reach the tip of the first toe or the third joint of the fourth toe. Generally $5 / 8-1 \frac{1}{4}$ inches in length, it is a strong jumper. This species is found along margins of swamps, marshes, lakes, streams and ditches. Active throughout the day and evening. Its voice resembles the sound of two marbles clicked together, usually 1-2 syllables in rapid succession.

\section{Green Treefrog Hyla gradiosa}

The Green Treefrog is typically bright green, yellow or greenish-gray. There is a defined light stripe along the upper jaw and sides of its body. The stripe is occasionally absent. Tiny, black-edged gold spots may be present on its back. Green Treefrogs have large toe pads and are $1 \frac{1 / 4}{4}-2 \frac{1}{2}$ inches in length. This species is generally found on vegetation near permanent water and occasionally found in brackish water. The voice is cowbell-like when heard at a distance, while nearer the sound is queenk-queenk with a nasal inflection.

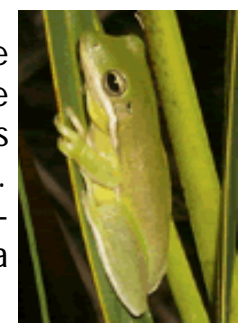

Squirrel Treefrog Hyla squirella

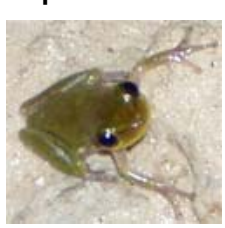
The Squirrel Treefrog is green to brown, plain to spotted, and may have yellow flecks on its back. A dark bar between its eyes may be present. This species has a poorly defined white stripe along the upper jaw and side of body which may be absent entirely. Squirrel Treefrogs have large toe pads and are $7 / 8-15 / 8$ inches in length. This species is found anywhere with moisture and insects. Adults commonly hide on the undersides of palm leaves, under loose bark or in tree holes. Its voice is a nasal trill. The 'rain call' is a scolding rasp and is very squirrel-like. 


\section{AnUrans of the Everglades Agricultural Area}

\section{Southern Chorus Frog Pseudacris nigrita}

The Southern Chorus Frog is light tan or gray with rough warty skin. It has three longitudinal rows of black spots, which may fuse into stripes. A black stripe through eye is present. Its toe tips are small and round. This species is $3 / 4-1 \frac{1}{4}$ inches in length. The Florida subspecies has a spotted upper lip. Primarily nocturnal, Southern Chorus Frogs may forage in daylight. Generally found in wet or moist grassy meadows, ponds, ditches and sinkholes and in damp leaf litter. Its voice is a rasping trill that is regularly repeated.

\section{Little Grass Frog Pseudacris ocularis}

Little Grass Frogs are tan to gray-green with a dark line through the eye and along side. The toes are slightly webbed and have rounded tips. A narrow, dark, middorsal stripe starting as a triangle between the eyes and extending to anal region is sometimes present. The smallest frog in North America, it is $1 / 2$ to $5 / 8$ inches long. Preferring low vegetation in moist, grassy environments near roadside ditches, pond margins and cypress bays, this species is generally found within 1-2

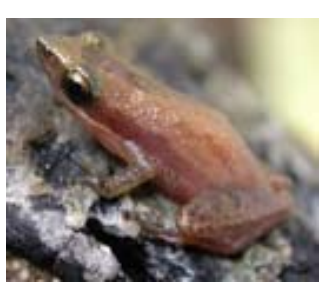
feet of the ground. Its voice is similar to the tinkling of glass and is very insect-like. The notes are a high and shrill 'set-see, set-see' and are inaudible to some people.

\section{Eastern Narrow-mouthed Frog Gastrophryne carolinensis}

The Eastern Narrow-mouthed Frog is reddish-brown to dark gray. This species often has broad light stripes along its middorsal area and its belly is strongly mottled. The snout-

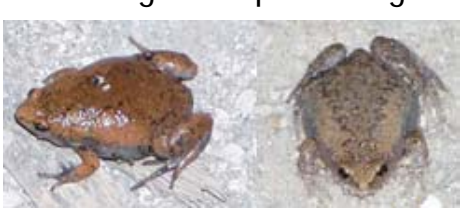
vent length is ${ }^{7} / 8-1 \frac{1}{2}$ inches. Commonly found along margins of water and areas with shelter and moisture. It feeds almost exclusively on ants and termites and is active only at night. Its voice is similar to the bleat of a lamb, occasionally with a very short peep.

Pig Frog Rana grylio

The Pig Frog is large and olive to grayish-green or dark brown. This species has a large tympanum and fully webbed hind feet. In males the tympanum is larger than the eye; while in females, it is the same size as or smaller than the eye. The fourth toe is webbed virtually to its tip. Pig Frogs have no dorsolateral ridges. Its length ranges from 31/4-6 inches. Strongly aquatic, it is found at edges of lakes, marshes and cypress bays, in water-lily prairies, or other emergent or floating vegetation. Crayfish are its main food source. Its voice is a short, explosive pig-like grunt which can be heard year-round.

\section{Southern Leopard Frog Rana sphenocephala}

The Southern Leopard Frog is generally green, brown or a combination of both colors. There is a light spot on the tympanum. This species has large spots between light colored dorsolateral ridges. Its general length is $2-31 / 2$ inches and specimens reaching 5 inches have been recorded. This frog is commonly found in all types of shallow, freshwater habitats and may be found in slightly brackish marshes. It will venture from water in summer to moist vegetation. Its voice is a short, chucklelike guttural trill.

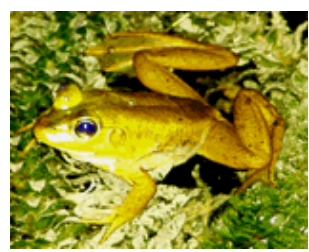




\section{AnUrans of the Everglades Agricultural Area}

\section{Greenhouse Frog Eleutherodactylus planirostris (Introduced)}

The Greenhouse Frog is either striped with dorsolateral light stripes or mottled, with irregular dark and light markings. This species is generally brown, but reddish tones may be present. Eyes are reddish. Its belly is white and may have fine brown stippling. This species is $5 / 8-1 \frac{1}{4}$ inches in length. It is a terrestrial frog found during the day or in dry weather under boards, leaf litter or where there is some moisture. It generally only moves about at night or in rainy weather. Eggs are laid among vegetation and froglets hatch directly from the egg, with no tadpole stage. Its voice is a series of 4-6 short, melodious, bird-like chirps

Marine Toad (Giant Toad, Cane Toad) Bufo marinus (Introduced)

The Marine Toad is large and brown to yellow-brown. Cranial crests are prominent. It has immense, deeply pitted parotoid glands that extend far down the sides of its body. It is generally 4-9 inches long in its native range; however it likely gets no larger than 7 inches

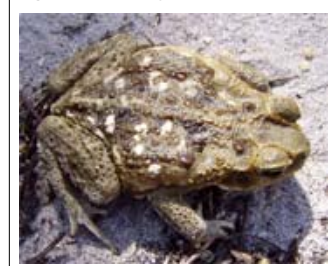
in the United States. Marine Toad females can weigh up to 3.3 pounds. This species is found in humid habitats with adequate hiding spots. It breeds where there is long-standing water present such as in ditches, canals, ponds and streams. The milky secretion from the parotoid glands is highly toxic and will burn eyes and can inflame skin. A dog or cat that bites this toad will become sick and may die. Its voice is a low-pitched trill, suggestive of the exhaust of a tractor.

\section{Cuban Treefrog Osteopilus sepentrionalis (Introduced)}

The Cuban Treefrog has warty skin and is green, bronze or gray. Its very large toe pads easily distinguish this treefrog from native species of southern Florida. Cuban Treefrogs are $1 \frac{1 / 2}{2}-5 \frac{1}{2}$ inches in length. This species is generally found in moist and shady places in trees and shrubs or around buildings. Nocturnal and highly predaceous, it will eat insects, spiders and other frogs. Cuban Treefrogs also have noxious skin secretions that may cause eyes and mucous membranes of potential predators, humans and pets to burn if they come

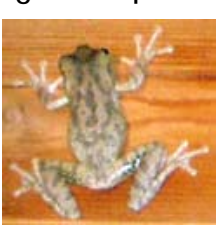
into contact with them. Its voice is a slightly rasping or grating snore. The voice is similar to that of the Southern Leopard Frog but is less vigorous and has a higher, more variable pitch. 